ownership. When he goes on to assert that plants have property, that a plant "possesses a definite territory," he seems to be playing with words. In the organ-pipe coral he finds an example of collective ownership, the individual polype also having something in the way of private property. In animals of a higher class, e.g. in ants, the notion of property does undoubtedly show itself. This paper is illustrated, and some of the pictures are excellent, but a picture of the nest of Formica rufa does not help us to understand the subject of property.

The fourth paper (by L. Wodon) is brief, and deals trenchantly with some sociological theories, notably with those of Karl Büchner, who maintains that primitive man was a non-social being. This creature of theory lived in lands where the abundance of natural products made any large output of energy on his part quite unnecessary. Our author satisfactorily disposes of this primitive lotus-eater.

Dr. E. Houzé has contributed a distinctly able paper (fascicule No. 5) on the Aryan and anthroposociology. $\mathrm{He}$ has a thorough grasp of his subject, his style is clear, and he has a fine sense of humour. The wonderful theories of the comparative philologist he sends to the limbo to which such theories must sooner or later find their way. He goes rather too far when he maintains that the Aryans were the creatures of the philologists. It is true, no doubt, as he argues, that no race has ever maintained its purity for any length of time unless it happened to be geographically secluded. The pure-bred Aryan stock that we were taught to picture to ourselves ranging over great part of Asia and all of Europe is a myth. But it is difficult to believe that the people who spoke the Aryan tongue in different parts of the world had not a fairly strong strain of kindred blood in them, though they intermarried freely with the tribes and peoples among whom they found themselves. Still, far too much has been made of the Aryans as a separate type, and Dr. Houzé is right to laugh at what has been called "Anglo-Saxon pandolichocephalism," a term invented to describe " the skull which has the honour of sheltering the brain that has guided the world." M. de Lapouge, the champion of the "dolichocephalic blond Aryan," is very severely dealt with. Dr. Houzé is a strong believer in natural selection. He keeps quite clear of the untenable view that it goes on in the organic world generally, whereas among men it has somehow become a thing of the past. "When the sun has baked the grass," he remarks, "it forces innumerable troops of antelopes to migrate : is not this the same cause that drives the Germans to embark at Hamburg for America? It is a question of food." Archarology, he holds, supplies the firmest foundation for anthropology, and he speaks with great respect of such men as de Morgan, Arthur Evans, and Flinders Petrie. Anthropometry he puts in its proper place. Nothing can be more absurd, as he says, than to make size of skull alone an absolute measure of brain capacity. When he discusses existing populations and their characteristics, Dr. Houzé shows great soundness of judgment. As to the question of town and country life, he holds that the commonly held opinion that towns "devour their inhabitants with rapidity " is at any rate an exaggeration. On the modernism of Teutonic civilisation he makes some very sensible remarks. The Teutons appeared late on the stage of history, and it was only their contact with GalloRoman civilisation that enabled them to reduce their legends to writing.

The last of the papers we are reviewing (by R. Petrucci) takes pains to prove that animal associations were developed independently of one another. They do not form the descent of birds and of men from simpler forms of life, the author shows a thorough understanding of the subject. About animal societies he has much interesting information-about the sociability of reptiles, about the form the family takes among fish, birds, and mammals. Apparently he does not point out (a curious omission) the interesting fact that the pairing instinct is strong only in those species in which the energy of both parents is required for the feeding or protection of the young. We regret that we have not space to deal more fully with this last paper. Those who are interested in animal associations would do well to study it.

NO. I 940, VOL. 75]

\section{IS THERE DETERMINATE VARIATION?}

$\mathrm{IN}$ an article published in Science of November 16, Prof.

Vernon L. Kellogg, of Stanford University, discusses the question as to the existence among organisms of determinate variation, that is to say, variation in the same or a similar direction in a large number of individuals of a single species. If such a factor does exist, one of the objections to the origin of species by natural selectionnamely, that small individual variations would be eliminated in a generation or two-disappears.

Prof. Kellogg's observations refer to variation occurring in the Californian flower-beetle, Diabrotica soror, inhabiting the Stanford University "campus." Large series of this chrysomelid beetle, varying from 500 to 1500 in number, were collected on that area in the years 1895 , I901, 1902, 1904, and 1905. Normally, the beetle shows six dark spots arranged in pairs on each wing-cover. Individuals show, however, a tendency to the transverse coalescence of the two middle or two lower spots on one or both elytra, or a longitudinal fusion of the three spots on each half of the elytron. In 1895 the majority of the beetles had twelve free spots on the two elytra, but among the variations there was a marked tendency to the transverse union of the two middle spots, either on one or both elytra, the percentage being 22.40 . In the years $1901-5$ a much larger percentage of this variation occurred, reaching 53.92 per cent. in one series in 1905 , and 65.40 per cent. in 1904 .

After adducing arguments to show that the variation is neither ontogenetic (that is, determined for each generation during development by external influences) nor the result of natural selection, Prof. Kellogg falls back on determinate variation. "If," however, he writes, "determinate variation is the explanation of this change in Diabrotica soror it is a determinate variation which is occurring only, apparently, in our particular locality. For in series of specimens of this beetle collected in other parts of California no such change seems to be going on, the old twelve-spots-free form being plainly the modal type. . . Why the species should be changing on our university campus and not changing in the regions south and north of us is a mystery whose solution I do not even dare to guess at. This solution must have to do with the cause of the variation of the species on our campus. But if one asks what is this cause, what it is that is producing determinate variation in Diabrotica, or in any other species, it must be mentioned that prior to any attempt to explain how determinate variation might be produced it is advisable to attempt to determine if determinate variation really exists. Is there determinate variation?"

\section{UNIVERSITY AND EDUCATIONAL INTE LLIGENCE.}

Lord Curzon of Kedleston, who was appointed to be the Romanes lecturer at Oxford for 1906, but was prevented from delivering the lecture, has been appointed the Romanes lecturer for this year.

Mr. William Smith, of Geneva, has, says Science, given Ioo, oool. to Hobart College to endow a college for women. It is also announced that Dr. Andrew Carnegie has offered to give 20,0ool. to Queen's University, Ontario, on condition that an additional sum of $80,000 \bar{l}$. be collected.

Mr. J. D. Rockefeller has made a New Year's gift to Chicago University of about $600,000 l$, which brings his total benefactions to the University up to $3,900,000 l$. The private gifts to universities and colleges in the United States, announced in these columns during last year, amounted to nearly $5,000,000 l$.

THE annual meeting of the Public School Science Masters' Association will be held at the University of London on Saturday, January 12. The president, the Rev. the Hon. E. Lyttelton, headmaster of Eton, will take the chair, and will read a paper on the place of science and of literature in a general education. Other subjects of papers upon which it is hoped discussion will take place are :- “The Internal Economy of School Science," by Mr. Thwaites, and "The Best Method of Introducing the Atomic Theory in Science," by Mr. F. R. L. Wilson. 